\title{
Unmasking a wild man: scientific analysis of Bertoldo di Giovanni's Shield Bearer in The Frick Collection
}

\author{
Elena Basso ${ }^{1 *}$ (D) Federica Pozzi ${ }^{1}$, Julia Day ${ }^{2}$ and Linda Borsch ${ }^{3}$
}

\begin{abstract}
Bertoldo di Giovanni (ca. 1440-1491) was the primary sculptor and medal worker for Lorenzo the Magnificent (14491492). Despite being one of the most prominent Italian Renaissance artists working in Florence, little is known about his workshop and practice. The Frick Collection, New York, owns a Shield Bearer, one of a small number of bronze statuettes attributed to Bertoldo predominantly based on stylistic grounds. This article presents the results obtained from the scientific analysis of The Frick statuette, including a detailed technical characterization of the casting alloy, gilding, solder, organic coatings, and other later alterations. An array of analytical techniques was employed, including $X$-radiography, micro- and portable X-ray fluorescence ( $\mu$ XRF and pXRF) spectroscopies, scanning electron microscopy with energy-dispersive X-ray spectroscopy (SEM/EDS), Raman and Fourier-transform infrared (FTIR) spectroscopies, and pyrolysis-gas chromatography/mass spectrometry (Py-GC/MS). This work supported a larger technical study of Bertoldo's statuettes and reliefs related to an exhibition organized by The Frick, which brought together a select group of medals, as well as eleven bronzes ascribed to the artist, including the museum's statuette. Close collaboration between conservators, curators, and scientists was critical throughout the study of the Shield Bearer, which also included extensive visual examination of the object in order to understand details of manufacture, identify sampling sites, and interpret the collected data. This study confirmed that The Frick figure was cast from the same brass alloy as a second very similar Shield Bearer in the Liechtenstein Collection, Vienna, suggesting that the two are a pendant pair that was likely cast simultaneously. In addition, analysis supported the assertion that the copper base on The Frick sculpture is original and assisted in identifying later alterations in both works. This focused research has expanded the current knowledge of the sculptor's materials and methods, enabling scholars to better contextualize his artistic production within the framework of Italian Renaissance sculpture.
\end{abstract}

Keywords: Bertoldo di Giovanni, 15th century, Italian Renaissance sculpture, Organic coating, Brass, Bronze, Gilding, Patina, Solder, Lost-wax cast

\section{Introduction}

In the 15th century, between late 1460 and early 1470 , a new kind of artwork appeared in the Florentine artistic milieu. Even if preceded by a few tentative efforts, bronze statuettes modeled by Bertoldo di Giovanni, Antonio del Pollaiuolo, and Bartolomeo Bellano reached their zenith,

\footnotetext{
*Correspondence: elena.basso@metmuseum.org

${ }^{1}$ Department of Scientific Research, The Metropolitan Museum of Art, 1000 Fifth Avenue, New York, NY 10028, USA

Full list of author information is available at the end of the article
}

becoming synonymous with the Italian Renaissance [1, 2]. As a disciple of Donatello (1386-1466), Bertoldo di Giovanni (ca. 1440-1491) was recognized in his time as the primary sculptor and medal worker for the great Florentine statesman and patron of the arts Lorenzo the Magnificent (1449-1492). Although a number of technical studies on 15th-century Renaissance bronzes can be found in the literature [3-12], Bertoldo's work was not the subject of serious technical study until recently [13]. With the exception of his medals, only a small number of his statuettes and reliefs are known to have survived.
Springer Open

(c) The Author(s) 2020. This article is licensed under a Creative Commons Attribution 4.0 International License, which permits use, sharing, adaptation, distribution and reproduction in any medium or format, as long as you give appropriate credit to the original author(s) and the source, provide a link to the Creative Commons licence, and indicate if changes were made. The images or other third party material in this article are included in the article's Creative Commons licence, unless indicated otherwise in a credit line to the material. If material is not included in the article's Creative Commons licence and your intended use is not permitted by statutory regulation or exceeds the permitted use, you will need to obtain permission directly from the copyright holder. To view a copy of this licence, visit http://creativeco mmons.org/licenses/by/4.0/. The Creative Commons Public Domain Dedication waiver (http://creativecommons.org/publicdomain/ zero/1.0/) applies to the data made available in this article, unless otherwise stated in a credit line to the data. 
Three sculptures have been unambiguously attributed to him based on archival documentation: Bellerophon Taming a Pegasus in the Kunsthistorisches Museum, Vienna, as well as Orpheus and the Battle relief in the Bargello National Museum, Florence [1, 14]. A recent study of Bertoldo's sculptural work, undertaken in preparation for a 2019 exhibition at The Frick Collection, New York, has expanded our understanding of his materials and methods and helped clarify the attribution based on stylistic grounds of previously questioned works [13].

The Frick Collection owns the only statuette in the United States that has been recognized as a cast by Bertoldo. The Shield Bearer (Fig. 1), formerly known as Heraldic Wild Man, was acquired by the museum from the collection of J. Pierpont Morgan (1837-1913) through Duveen Brothers in 1916. Prior to 1905, it was in the hands of Charles Loeser (1864-1928), an American collector and art historian living in Florence [14]. A similar Shield Bearer in the Liechtenstein Collection, Vienna, was purchased in 1880 by Prince Johann II von Liechtenstein from Stefano Bardini (1836-1922), and it has remained in that collection ever since. Willem von Bode was the first to attribute these works to Bertoldo and propose that they are a related pair [15]. Only scant information is available about the statuettes prior to the end of the 19th century, and no additional archival documents have been found to establish their connection to Bertoldo. However, their physical characteristics are consistent with Bertoldo's documented bronzes and scholars largely agree that these statuettes are by the artist [14].

In recent decades, technical examination and scientific analysis of Renaissance bronzes have demonstrated the potential for fruitful collaborative research that bridges the fields of art history, conservation, and science [1625]. These studies have provided data to support historical and artistic contextualization, and in some cases solved controversies about authenticity [26]. Compared to the analysis of alloys, only a few studies of Renaissance patinas can be found in the literature [21, 27-30]. It can be very difficult, sometimes impossible, to visually or analytically distinguish between original and later surface treatments, including gilding, chemical patination, and organic coatings. For example, surface coatings are often poorly preserved, and a substantial amount of sampled material is generally required to obtain reliable analytical results. Scientific analysis is further complicated by the
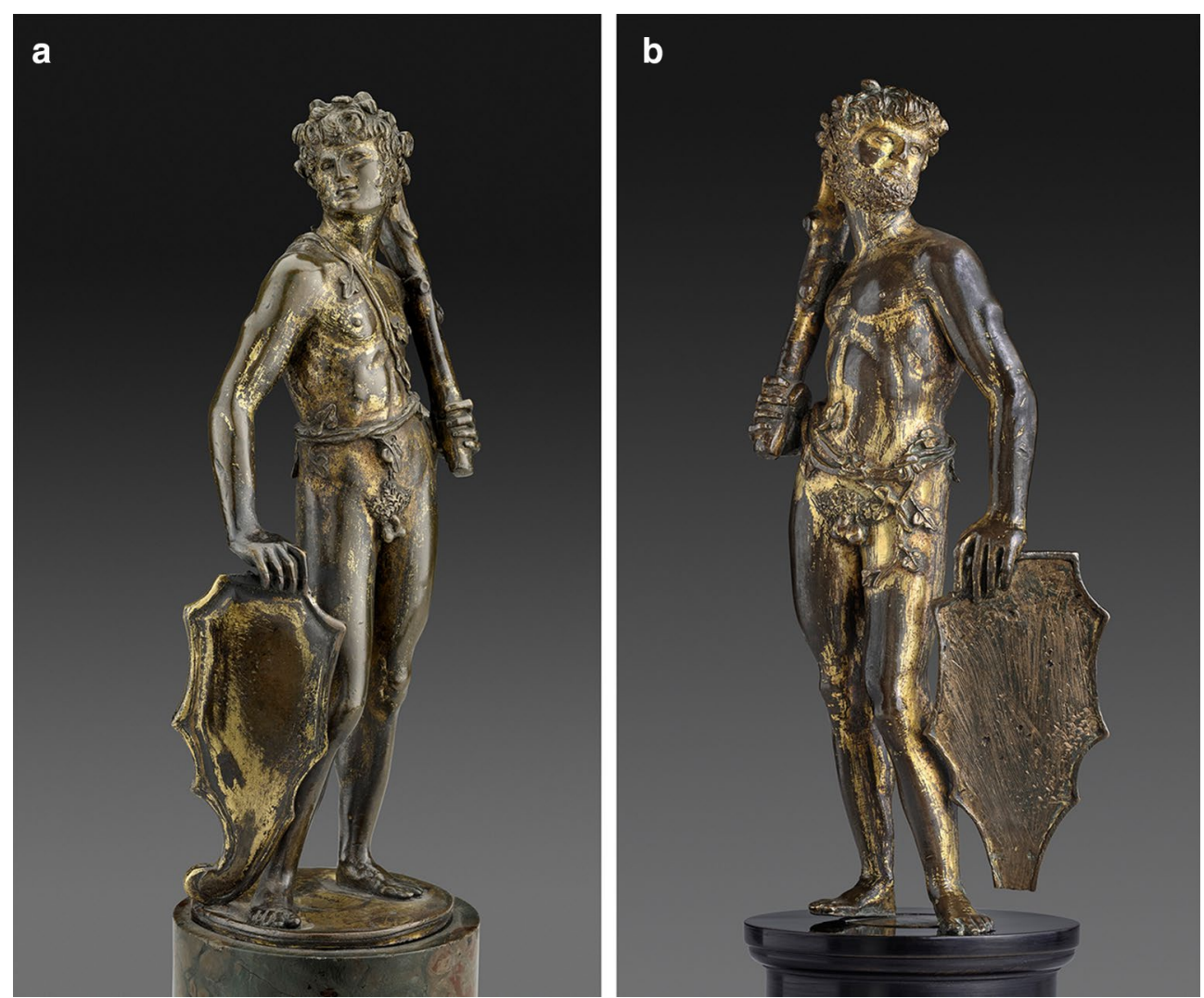

Fig. 1 Shield Bearer, Bertoldo di Giovanni, ca. 1470-80, h. 22.5 cm: a The Frick Collection, acc. no. 1916.2.03 and b The Liechtenstein Collection, acc. no. 258 
fact that metal surfaces can oxidize and otherwise interact with coatings that themselves degrade or are altered over time [21]. Although analysis with non-invasive techniques is generally preferred, sometimes micro-invasive approaches are necessary to yield a more accurate characterization of metal alloys, surface treatments, and later repairs. This information may clarify details of sculpting and casting that are specific to an artist or workshop, and can also inform decisions related to conservation treatment.

In this context, in-depth scientific analysis of The Frick Shield Bearer was undertaken to investigate the statuette's materials and fabrication techniques, with the aim of corroborating its stylistic attribution to Bertoldo and substantiating its connection to the Liechtenstein Shield Bearer. To achieve this goal, an array of analytical techniques was employed, including digital X-radiography, micro- and portable X-ray fluorescence ( $\mu \mathrm{XRF}$ and pXRF) spectroscopy, scanning electron microscopy with energy-dispersive X-ray spectroscopy (SEM/EDS), Raman and Fourier-transform infrared (FTIR) spectroscopies, and pyrolysis-gas chromatography/mass spectrometry (Py-GC/MS). Results of this work were compared with data obtained from the analysis of Bertoldo's bronzes in other collections by the corresponding study conducted at The Frick. Previous research suggests that many 15th-century sculptors, including Bertoldo, cast primarily in low tin bronze. It is interesting to note that the Shield Bearers - the artist's only gilded statuettes-were the lone exceptions that were identified as brass in The Frick survey. Analysis of the solder, in conjunction with radiography, confirmed that the copper base on The Frick statuette is original, while visual examination and radiographs provided additional evidence of later alterations to other areas of the cast. This research supported the larger study to clarify the attribution of Bertoldo di Giovanni's bronzes through technical examination and alloy analysis [13].

\section{Experimental}

The Frick Shield Bearer was analyzed with a combination of non-invasive and micro-invasive techniques. Materials studied include the metal alloy, solder, gilding, and organic coatings. The sculpture was examined under magnification and using X-radiography to investigate its manufacturing techniques and to evaluate the extent of any possible repairs. The alloy composition was measured non-invasively by means of pXRF and $\mu \mathrm{XRF}$, which are often preferred over methods that involve sampling of artworks and have proven valuable for the characterization of copper alloy casts [31-34]. Accuracy of these surface techniques for metal alloy analysis may be limited by the presence of gilding, other surface treatments, and corrosion products. Although there is some evidence that organic coatings may interfere with XRF analysis [35], this influence appears to be minimal [36]. In addition to non-destructive methods, seven microscopic samples (Table 1) were removed from the statuette using micro-scalpels for analysis with multiple instrumental techniques. Among these, SEM/EDS was used to characterize the gilding and solders; additionally, Raman and FTIR spectroscopies, as well as Py-GC/MS, provided information on the composition of the dark organic coatings and on the identity of the corrosion products.

$X$-radiography Radiography was performed using Philips MG321 X-ray and Carestream HPX-1 CR systems, equipped with a Philips MCN321 tungsten (W) target ceramic tube that was operated with a 3-mm aluminum (Al) primary beam filter and collimator, at a distance from the imaging plate of $90 \mathrm{~cm}$, using a Philips MGC30 control unit. CR high resolution XL Blue Digital Imaging Plates were sandwiched between lead $(\mathrm{Pb})$ filters $(0.0127 \mathrm{~cm}$ in thickness above the plate and $0.0254 \mathrm{~cm}$ below). Exposure times were set to 30-60 s, with voltage and current ranging from $225 \mathrm{kV}$ and $4.2 \mathrm{~mA}$ to $320 \mathrm{kV}$ and $3.0 \mathrm{~mA}$. Images were processed

\section{Table 1 Samples removed from The Frick Shield Bearer}

\begin{tabular}{lll}
\hline Sample & Description & Sampling location \\
\hline S1 & Scraping of black organic coating & Back of proper right knee \\
S2 & Scraping of possibly original gilding & Back edge of panpipes \\
S3 & Scraping of possibly later gilding & Upper portion of shield \\
S4 & Fragment of solder & Inner portion of proper right foot \\
S6 & Fragment of solder & Area at solder line from join between top plate and beveled edge \\
S7 & Fragment of solder & Area at solder line from join between top plate and beveled edge \\
\hline
\end{tabular}


using Kodak Industrex software with preset Edge filter 2 to increase contrast and highlight detail.

$X R F$ Two instruments were used to collect data on the alloy composition. Analysis by $\mu \mathrm{XRF}$ was carried out exclusively on The Frick statuette with an openarchitecture Bruker Artax XRF spectrometer using unfiltered rhodium ( $\mathrm{Rh}$ ) radiation at $50-\mathrm{kV}$ voltage, 700- $\mu \mathrm{A}$ current, and acquiring each spectrum live-time for $60 \mathrm{~s}$ in air and with a 1-mm collimator. Spectra were collected on several spots, selected among locations with minimal visible gilding, and quantitative data were calculated using the fundamental parameter-based quantification method by means of the MQuantCalib software provided by Bruker. The unit was calibrated with a Copper CHARM set [37]. Analysis by pXRF was conducted on the Liechtenstein statuette using a Tracer 5i system equipped with a Rh window X-ray tube and a silicon drift detector (SDD), with an average resolution greater than $140 \mathrm{eV}$ at 250,000 cps for the full width at half maximum of the manganese $(\mathrm{Mn}) \mathrm{K \alpha}$ line. The instrument was operated in air at $50 \mathrm{kV}$ and $17 \mu \mathrm{A}$, and each spectrum acquired for $60 \mathrm{~s}$ (live time $52 \mathrm{~s}$ ). Analysis was carried out with the addition of a 75- $\mu \mathrm{m}$ copper $(\mathrm{Cu}), 25-\mu \mathrm{m}$ titanium $(\mathrm{Ti})$, and $200-\mu \mathrm{m}$ aluminum (Al) filter, and the size of the spot analyzed was approximately $8 \mathrm{~mm}$. Quantification of the spectra was performed using CloudCal v.2.0 [38] and a calibration set incorporating 33 copper alloy certified reference materials (CRMs) [39]. The CRMs consist of metal disks: fourteen from the Copper CHARM set, seven from The Frick, and twelve from the Garman Art Conservation Department, Buffalo State College, SUNY. These disks were produced by MBH Analytical Ltd., European Commission IRMM, ARMI, and the US Department of Commerce NIST (or NBS).

SEM/EDS Analysis was conducted on samples mounted with carbon tape on an aluminum stub, using a FE-SEM Zeiss Ligma HD system equipped with an Oxford Instrument X-MaxN 80 SDD detector. Backscattered electron (BSE) imaging, as well as EDS elemental spot analysis and mapping, were performed under high vacuum conditions with an accelerating voltage of $20 \mathrm{kV}$, on uncoated samples, at an 8.5-mm working distance.

Raman Analysis was performed using a Bruker Senterra Raman spectrometer equipped with an Olympus $50 \times$ microscope objective and a charge-coupled device $(\mathrm{CCD})$ detector. A continuous wave diode laser emitting at $785 \mathrm{~nm}$ was used as the excitation source, and two holographic gratings (1800 and 1200 rulings $/ \mathrm{mm}$ ) provided a spectral resolution of $3-5 \mathrm{~cm}^{-1}$. The output laser power, number of scans, and integration time were adjusted according to the Raman response of the sample analyzed.
FTIR Analysis was conducted with a Hyperion 3000 FTIR spectrometer equipped with a mercury cadmium telluride (MCT) detector. The sample was crushed in a diamond anvil cell (Spectra Tech) and analyzed as a bulk in transmission mode through a $15 \times$ objective. Spectra were collected in the $4000-600 \mathrm{~cm}^{-1}$ range at a resolution of $4 \mathrm{~cm}^{-1}$. Each spectrum was obtained as the sum of 256 scans. Spectra were interpreted by comparison with published literature and library databases available at The Met, as well as IRUG Edition 2000 and 2007.

$P y$-GC/MS Analysis was performed on an Agilent $5973 \mathrm{~N}$ gas chromatograph equipped with a Frontier PY-2020iD Double-Shot vertical furnace pyrolyzer fitted with an AS-1020E Auto-Shot autosampler. The GC was coupled to a $5973 \mathrm{~N}$ single quadrupole mass selective detector (MSD). Samples of 30-50 $\mu \mathrm{g}$ were weighed out in deactivated pyrolysis sample cups (PY1-EC80F Disposable Eco-Cup LF) on a Mettler Toledo UMX2 Ultra microbalance. Samples were then either pyrolyzed without derivatization or derivatized with tetramethyl ammonium hydroxide (TMAH) before pyrolysis. Derivatization took place in the same cups as follows: $3-4 \mu \mathrm{l}$ of 25\% TMAH in methanol (both from Fisher Scientific), depending on the sample size, were added directly to the sample in each cup with a 50- $\mu \mathrm{l}$ syringe and, after $1 \mathrm{~min}$, loaded onto the autosampler. The interface to the GC was held at $320{ }^{\circ} \mathrm{C}$ and purged with helium for $30 \mathrm{~s}$ before opening the valve to the GC column. The samples were then dropped into the furnace and pyrolyzed at $550{ }^{\circ} \mathrm{C}$ for $30 \mathrm{~s}$. The pyrolysis products were transferred directly to a DB-5MS capillary column $(30 \mathrm{~mm} \times 0.25 \mathrm{~mm} \times 1 \mu \mathrm{m})$ with the helium carrier gas set to a constant linear velocity of $1.5 \mathrm{~mL} / \mathrm{min}$. Injection with a 30:1 split was used, in accordance with the sample size. The GC oven temperature program was: $40{ }^{\circ} \mathrm{C}$ for $1 \mathrm{~min} ; 10{ }^{\circ} \mathrm{C} / \mathrm{min}$ to $320{ }^{\circ} \mathrm{C}$; isothermal for $1 \mathrm{~min}$. The Agilent 5973N MSD conditions were as follows: transfer line at $320^{\circ} \mathrm{C}$, MS Quad $150{ }^{\circ} \mathrm{C}$, MS Source $230{ }^{\circ} \mathrm{C}$, electron multiplier at approximately $1770 \mathrm{~V}$; scan range 33-550 amu. For samples run with TMAH, the detector was turned off for 3 min to avoid saturation by excess derivatizing agent and solvent. Data analysis was performed on an Agilent MSD ChemStation D.02.00.275 and results compared with the NIST 2005 spectral libraries.

\section{Results and discussion Casting techniques}

$\mathrm{X}$-radiography provided critical information on the manufacture and alterations of the Shield Bearers. Both figures are evenly radiopaque with no evidence of an internal armature or core, verifying that they are solid casts that were made in the same way (Fig. 2). Solid lostwax casts are consistent with many statuettes of this 


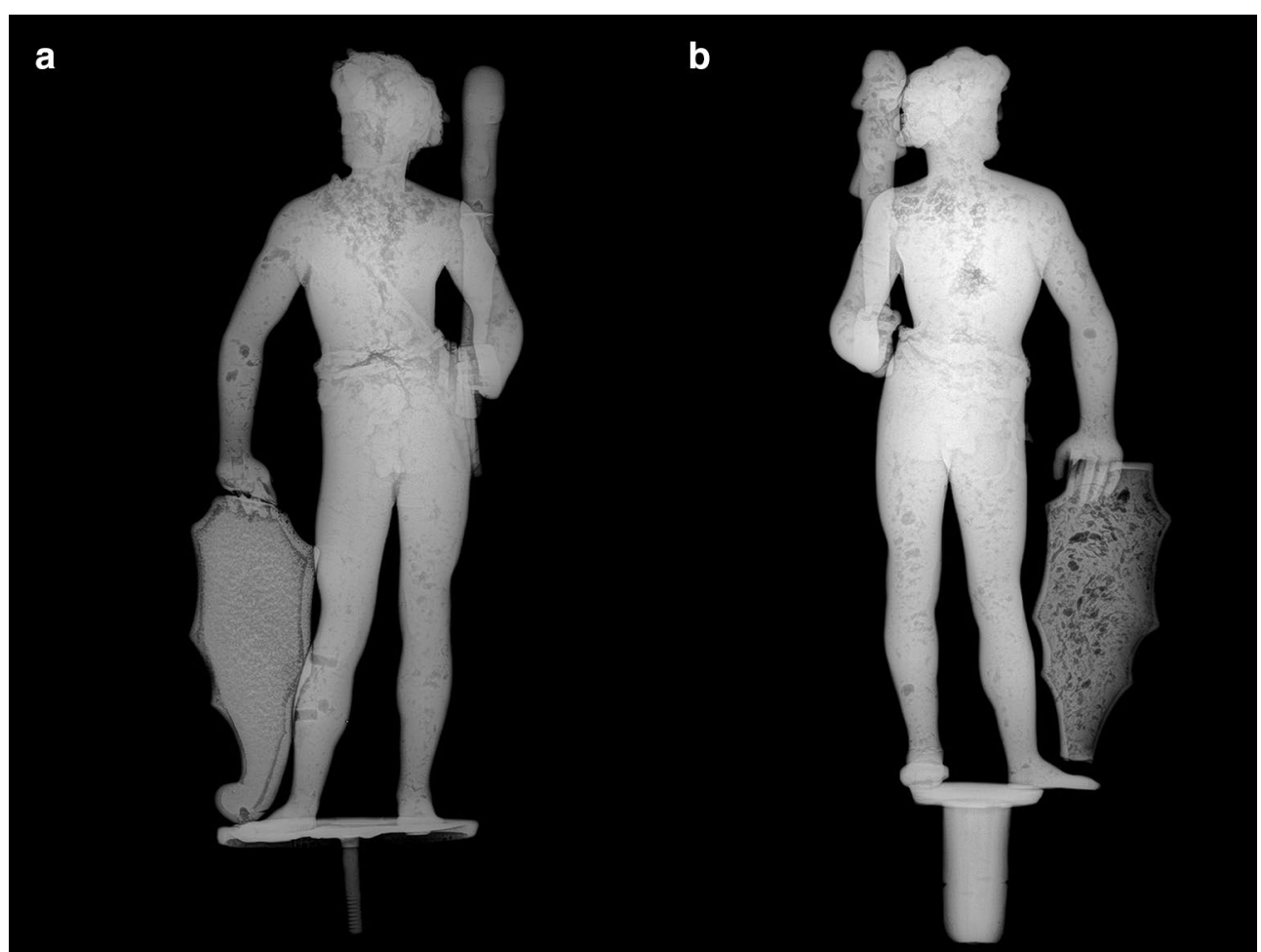

Fig. 2 Overall radiographs of $\mathbf{a}$ The Frick statuette and $\mathbf{b}$ the Liechtenstein statuette

period when sculptors and founders were still struggling with hollow casting [4]. The radiographs display scattered dark spots throughout the figures, revealing areas of porosity that resulted from gases that were trapped in the molten metal during the initial pour or were introduced into the cast as the metal shrank on cooling (Fig. 2a). A particular area of retraction porosity, which originates from the preferential cooling of the metal, is noted in the neck and upper chest of both figures. The location of this porosity would suggest that the statuettes were cast with their heads up and the molten metal was directly fed into the top of the invested mold.

Although the figures each hold a club and shield in either hand, early photographs of The Frick Shield Bearer show that one or both of the attributes were damaged before the sculpture entered the collection. Radiographs indicated that the lower club on The Frick statuette was part of the original cast, and that both the shield and upper half of the club exhibit fine, evenly distributed porosity, more typically observed in 19th-century castings. Radiographs of the Liechtenstein Shield Bearer reveal that the attributes display an uneven internal porosity, which is consistent with that detected in the rest of the statuette, supporting the hypothesis that they were cast as part of the figure (Fig. 2b). The current assumption is that The Frick figure originally held attributes that were cast as one with the figure and were similar to the existing restorations, which were likely modeled on the Liechtenstein example.

Radiographs clarified additional details of the repairs on The Frick statuette. Small dark rectangular shapes that are visible in areas where the shield joins the figure's right hand, lower right leg, and base, confirm the location of small holes drilled across joins for insertion of attachment pins (Fig. 3a). The two horizontal holes in the leg, which are currently filled but no longer contain pins, could represent evidence of a now missing restoration to an earlier damage, or possibly even a repair to an original casting flaw in the shield. The flat or rounded ends of most of these drill holes do not resemble the pointed holes typically created with modern twist drills, which are evident in the more recent repairs to the club (Fig. 3b). Radiopaque solder, visible as whiter areas on the radiographs, is also evident at the repairs in the club, hand, and base (Fig. 3).

The Frick statuette base was constructed of three metal sections soldered together: a cast circular plate, a beveled ring around the top edge, and a second ring soldered around the underside. This construction appears to be unusual for this period since surviving bases were generally cast in one piece. The threaded copper rod that extends from the underside and the circular plugs 


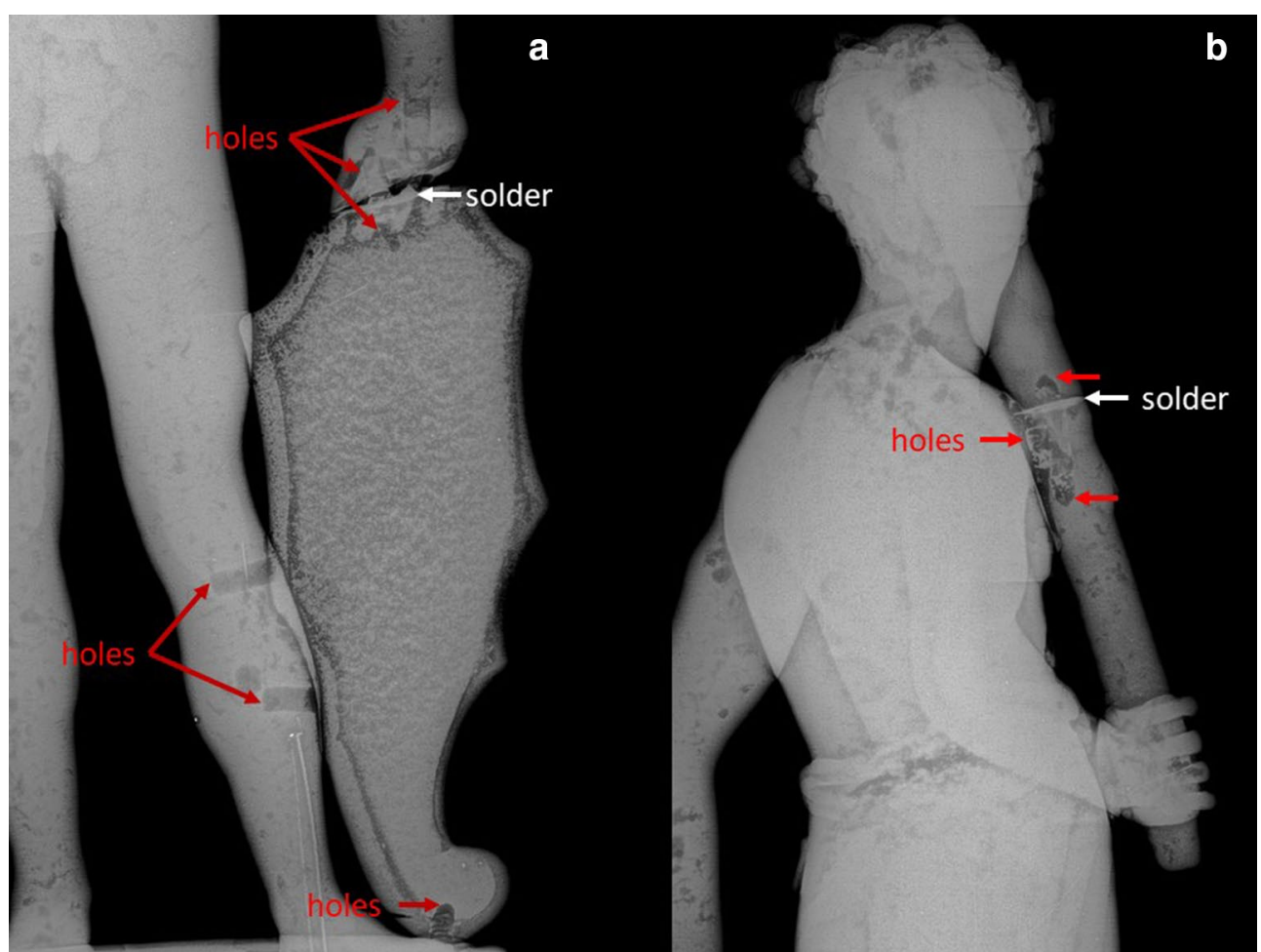

Fig. 3 Detail radiographs of repairs on The Frick statuette of the a shield, right leg and hand, and base, and $\mathbf{b}$ upper club

soldered into holes in the front and rear of the main plate are later additions (Fig. 4a). Radiographs of the base reveal that a pair of cylindrical rivets connecting the feet of the figure to the base are cut off casting gates that are continuous with the legs of the figure (Fig. 4b). These truncated gates were inserted through similarly sized holes in the base and flattened by hammering; silver solder was detected by SEM/EDS in sample S4 removed from the right foot, indicating that the mechanical join was also soldered. The practice of incorporating casting gates to function as joining elements has been noted in other early Renaissance works $[39,40]$. The Liechtenstein statuette likely had a similar base, but at some point it was damaged or intentionally removed and the gates on the underside of its feet were cut off. The base has since been replaced with a small modern brass plate that is attached with threaded screws; this was done prior to its sale in 1880 to the Liechtenstein Collection. A damage and subsequent repair to the statuette's proper right ankle may have resulted from this later alteration.

\section{Metal alloys}

XRF was performed to determine the composition of the metal alloys used for casting the Shield Bearers. Results, expressed as weight percent and normalized to $100 \%$, are summarized in Table 2 . All analyses were carried out using $\mu \mathrm{XRF}$, unless otherwise noted in the table. Data on The Frick statuette's club are not included due to interference of the gilding with quantitative analysis. The designation of the alloy terms used henceforth is based on classifications reported in the literature [31,39]. The statuettes were both cast in a medium zinc brass, as shown by the approximate contents of copper $(\mathrm{Cu}, 84$ $w t \%)$, zinc ( $\mathrm{Zn}, 12.50 \mathrm{wt} \%)$, lead (Pb, $2.15 \mathrm{wt} \%)$, and tin (Sn, $0.60 \mathrm{wt} \%$ ), which were identified along with minor traces of antimony $(\mathrm{Sb})$, arsenic (As), and nickel (Ni). The shield on the Liechtenstein statuette was found to have the same composition as the figure, verifying that it belongs to the original cast. The composition of the rivets under the feet of The Frick statuette was found to be identical to that of the figure, which proves that they were part of the original casting. The lower half of the club on the same statuette displays a qualitative composition that compares to the figure, which likewise confirms that it is original. The shield on The Frick statuette was identified as a quaternary alloy of $82.30 \mathrm{wt} \% \mathrm{Cu}, 5.90 \mathrm{wt} \% \mathrm{Zn}, 5.46$ $\mathrm{wt} \% \mathrm{~Pb}$, and $3.69 \mathrm{wt} \% \mathrm{Sn}$, with traces of $\mathrm{Sb}$, As, and $\mathrm{Ni}$; this alloy differs markedly from that used to cast the figure, establishing that it is a replacement. Qualitative analysis of the upper club identified the alloy as a medium zinc brass with higher levels of $\mathrm{Ni}$ and lower levels of $\mathrm{Pb}$ than the figure, further substantiating that it is a later 


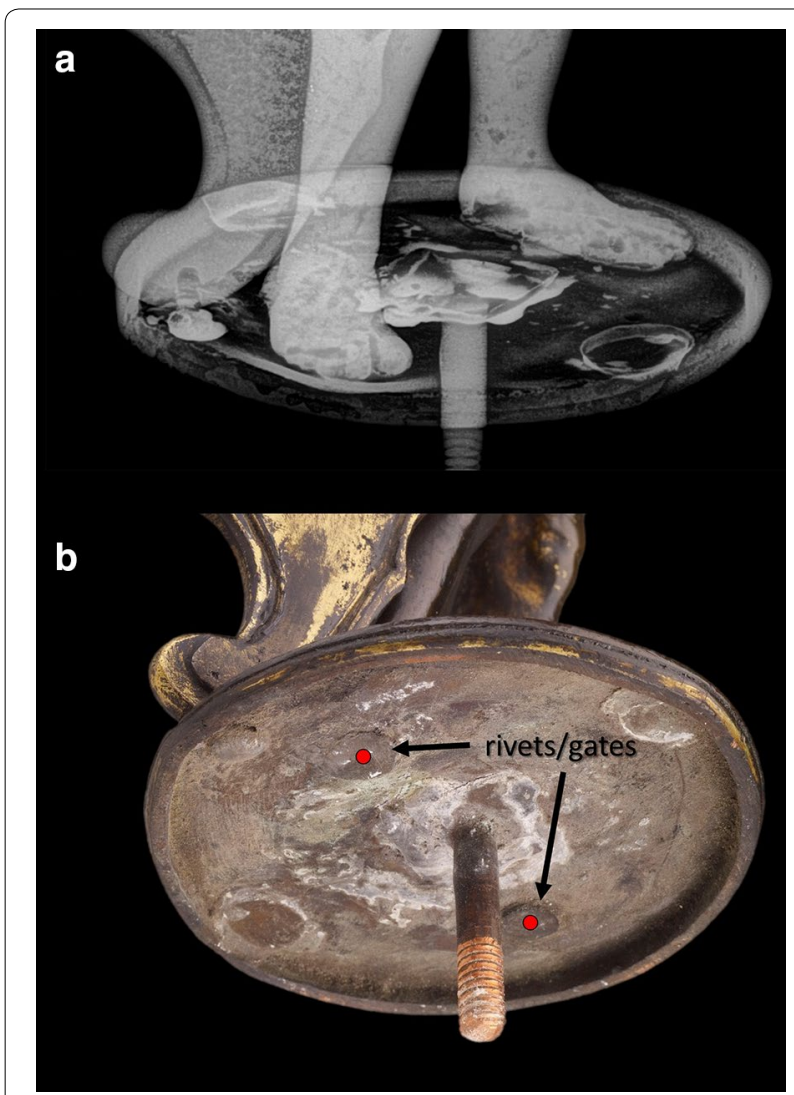

Fig. 4 a Radiograph of the base of The Frick Shield Bearer, showing $\mathbf{b}$ the rivets below the figure's feet

restoration. Overall, the analytical evidence supports both the archival records and radiographs, affirming that The Frick Shield Bearer's upper club and shield are likely later replacements.

It was interesting to discover that the base of The Frick statuette is composed of $99 \mathrm{wt} \% \mathrm{Cu}$, with traces of $\mathrm{Pb}, \mathrm{Sb}$, and As, differing significantly from the brass alloy used to cast both figures; this practice of employing different alloys for separately produced elements has been noted in other Renaissance objects [39, 40]. XRF measurements detected the presence of Ag in combination with $\mathrm{Cu}$ in the solder used to join the top plate and the beveled upper ring of the base (Fig. 5), and SEM/EDS analysis of small samples (S6 and S7) confirmed that the solder is made of a $\mathrm{Ag}-\mathrm{Cu}$ alloy. The equilibrium microstructures visible in the elemental X-ray maps (Fig. 6) illustrate a combination of proeutectic $\mathrm{Cu}$ and lamellar $\mathrm{Cu}-\mathrm{Ag}$ eutectic, compatible with an $\mathrm{Ag}_{75}-\mathrm{Cu}_{25}$ alloy [41]. Alloys with similar compositions, known as "hard solders", were reportedly in use in Italy during the 16th century [42-44]. These differ from $\mathrm{Zn}$ - and even brass-containing hard solders that are more typical after the 18th century [45]. The identification of $\mathrm{Ag}-\mathrm{Cu}$ solder, more common for early manufacture, supports the conclusion that the base of The Frick statuette is original and the assumption that the Liechtenstein statuette may have had a similar base.

In order to define a possible trend in the artist's use of $\mathrm{Cu}$ alloys, the elemental compositions of the Shield Bearers were compared with data obtained by pXRF analysis and previously reported by one of the authors [13] of eleven casts attributed to Bertoldo. All but one of these casts included in such previous study are largely accepted as works by Bertoldo [1, 46], based on stylistic similarities to the three established casts mentioned earlier. This data was plotted on a $\mathrm{Cu}-\mathrm{Sn}-\mathrm{Zn}$ ternary diagram (Fig. 7) and is reproduced here to show the difference between the alloy of the Shield Bearers and those of the casts thought to be produced by Bertoldo. The diagram clearly illustrates that the ascribed casts fall into two main alloy categories: in detail, the Shield Bearers were cast in a medium zinc brass containing approximately $80 \mathrm{wt} \% \mathrm{Cu}$ and 11 $\mathrm{wt} \% \mathrm{Zn}$, forming a distinct cluster that differs from the artist's nine other statuettes and reliefs, which were cast in a low tin bronze alloy of approximately 84-92 wt\% Cu and $2-7 \mathrm{wt} \% \mathrm{Sn}$.

The Frick and Liechtenstein Shield Bearers' elemental composition was virtually identical for both casts (Table 2), supporting the curatorial theory that they were cast simultaneously as a loosely mirrored pair [14]. Since the most recent curatorial consensus has confirmed that these works are by Bertoldo, one possible explanation for this difference from the artist's usual casting alloy is that he may have used a different foundry or purchased ingots of relatively clean brass to cast the statuettes. Artists have historically preferred brass over bronze for gilding, since it more closely resembles the color of gold and disguises lacunae resulting from flaws in gilding and also later surface wear. Furthermore, since antiquity, sculptors have been aware of the fact that the best copper alloys for mercury gilding are those in which certain alloying constituents are kept to a minimum, particularly lead [47, 48].

\section{Surface treatments}

The gilding on both statuettes is worn and displays remnants of a black coating in protected areas, which may have been applied overall as part of a later treatment to masque surface wear or to impart a dark appearance to the bronze. Despite published studies that focus on surface treatments of 16 th- to 18th-century bronzes [21, 27-30], there is limited information and no scholarly consensus on the original appearance of 15th-century Florentine bronzes. However, according to available historical treatises from the Renaissance and later Baroque periods, surfaces could be gilded or made dark by heat 


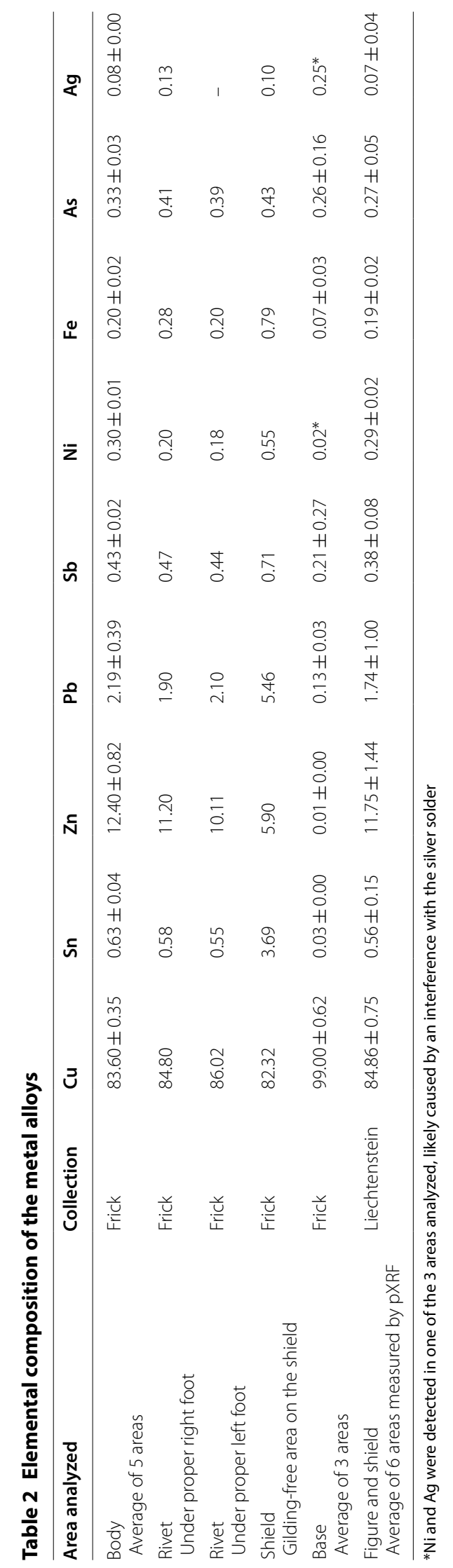




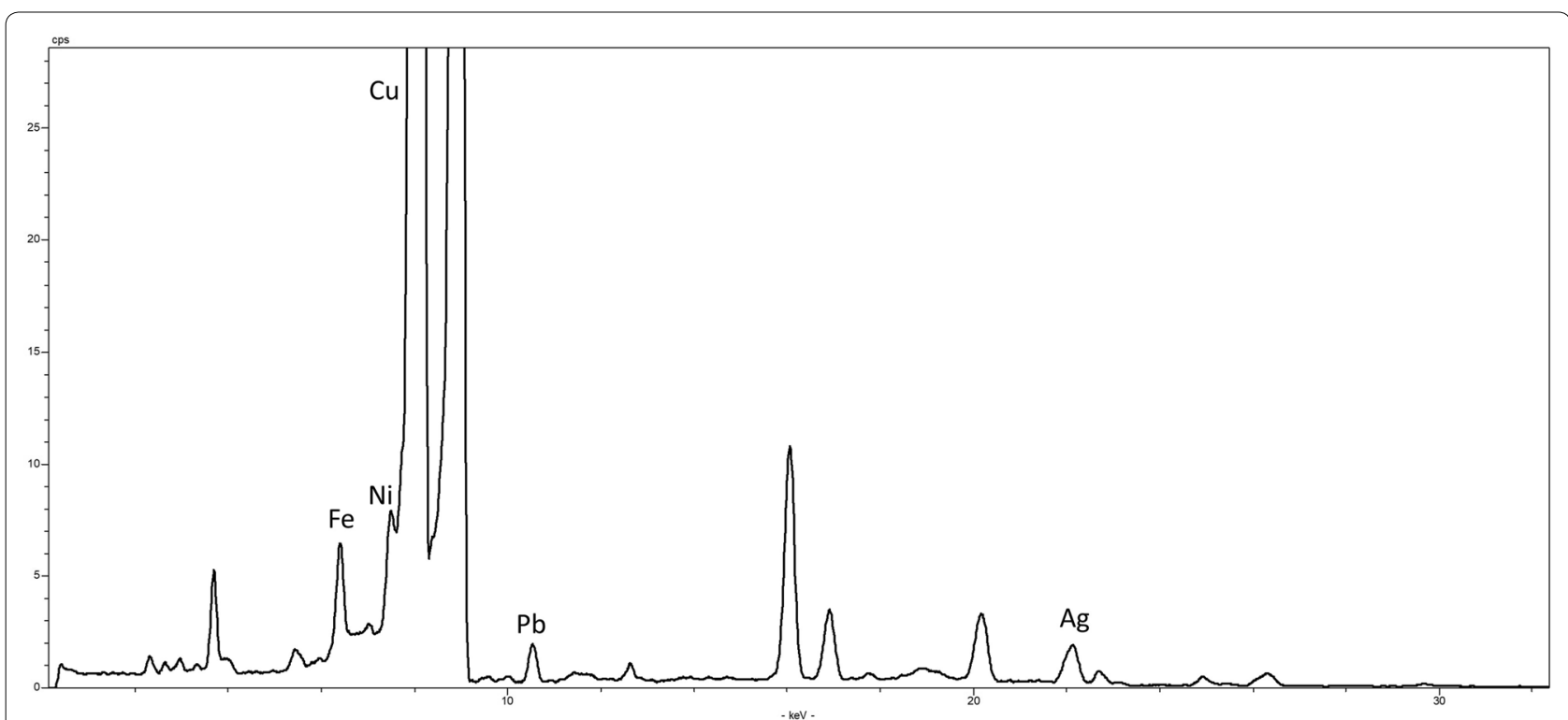

Fig. 5 XRF spectrum of an area corresponding to the soldering line between the top plate and the beveled edge, showing the presence of $\mathrm{Cu}$ and $\mathrm{Ag}$, in addition to traces of a few other elements
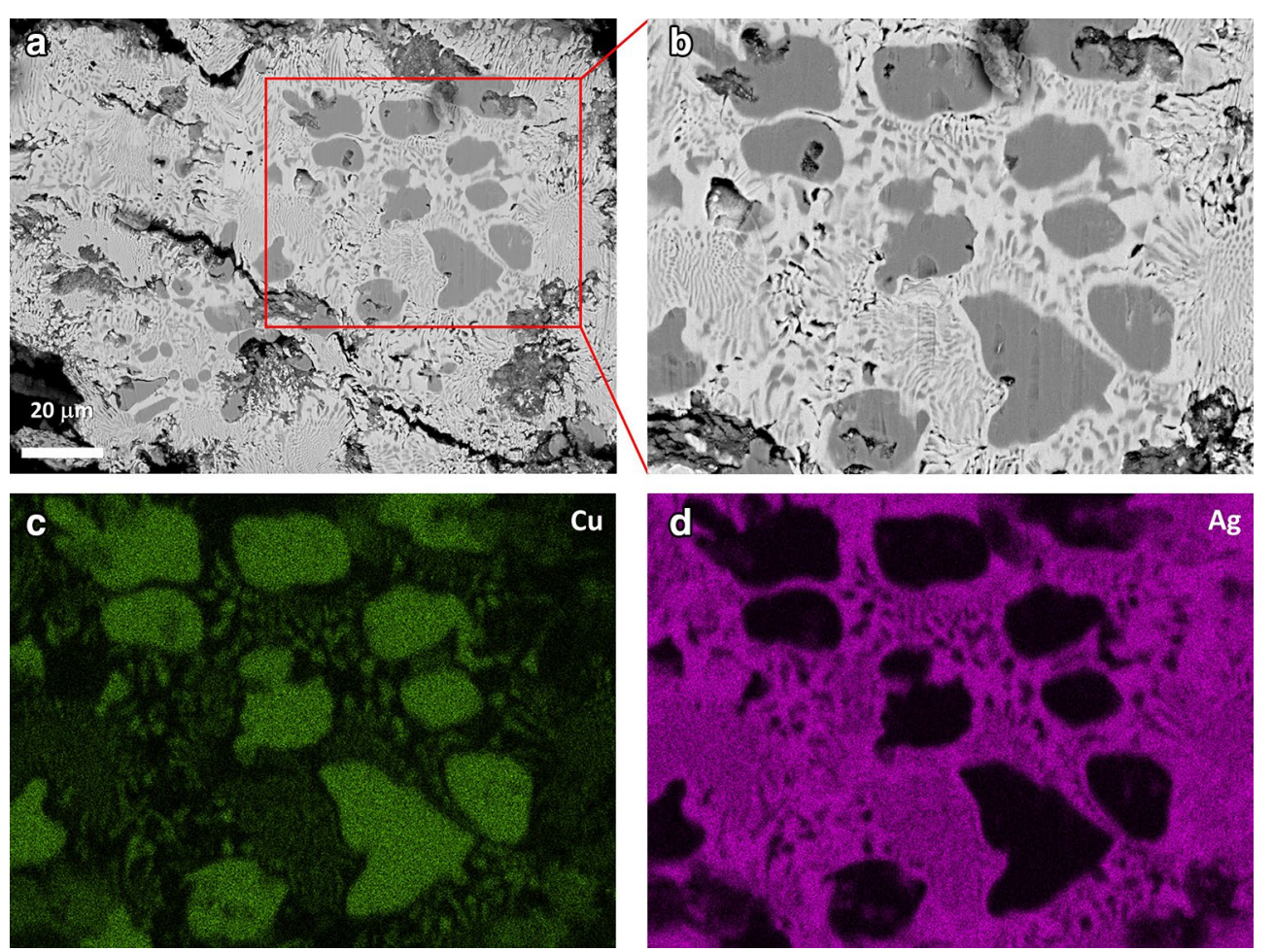

Fig. 6 BSE images of $\mathbf{a}$ a portion of sample S6, i.e. a fragment of solder, showing the microstructure constituting the Cu-Ag solder, and $\mathbf{b}$ a detail of the microstructure (red square). $\mathbf{c}$, d X-ray elemental maps illustrating the distribution of Cu and Ag, respectively 


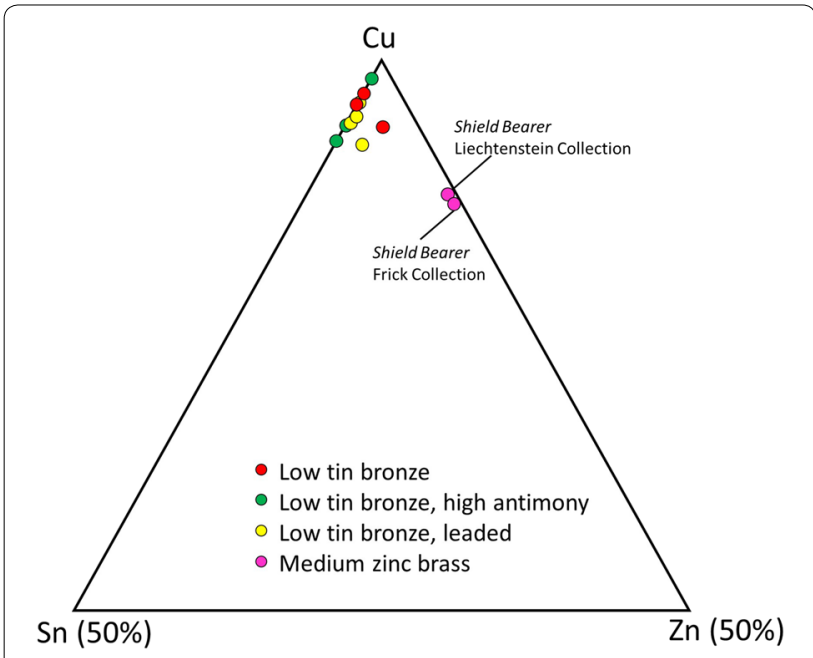

Fig. $7 \mathrm{Cu}-\mathrm{Sn}-\mathrm{Zn}$ ternary diagram, summarizing the compositional clustering of the twelve casts attributed to Bertoldo based on XRF elemental data treatment alone or by the application of oil-based resin varnishes that were subsequently heated [18, 21, 49-51]. These coatings served both an artistic and functional purpose: to improve the beauty of the artwork, while also disguising original repairs to casting flaws such as porosity, which were common at this period [52-55]. However, in the 19th century, there was a preference for bronzes to look dark, and gilt or resin varnish surfaces were often covered using black coatings. In the present study, the gilding and organic coatings on both statuettes were examined under magnification; subsequently, only the surface of The Frick Shield Bearer was sampled and analyzed micro-invasively using various techniques.

\section{Gilding}

Mercury amalgam (or fire) gilding was used on bronze reliefs and statues in Italy at this period; however, to the authors' knowledge, the Shield Bearers may be the only two 15th-century statuettes that have been analyzed and still appear to retain their original gilding.
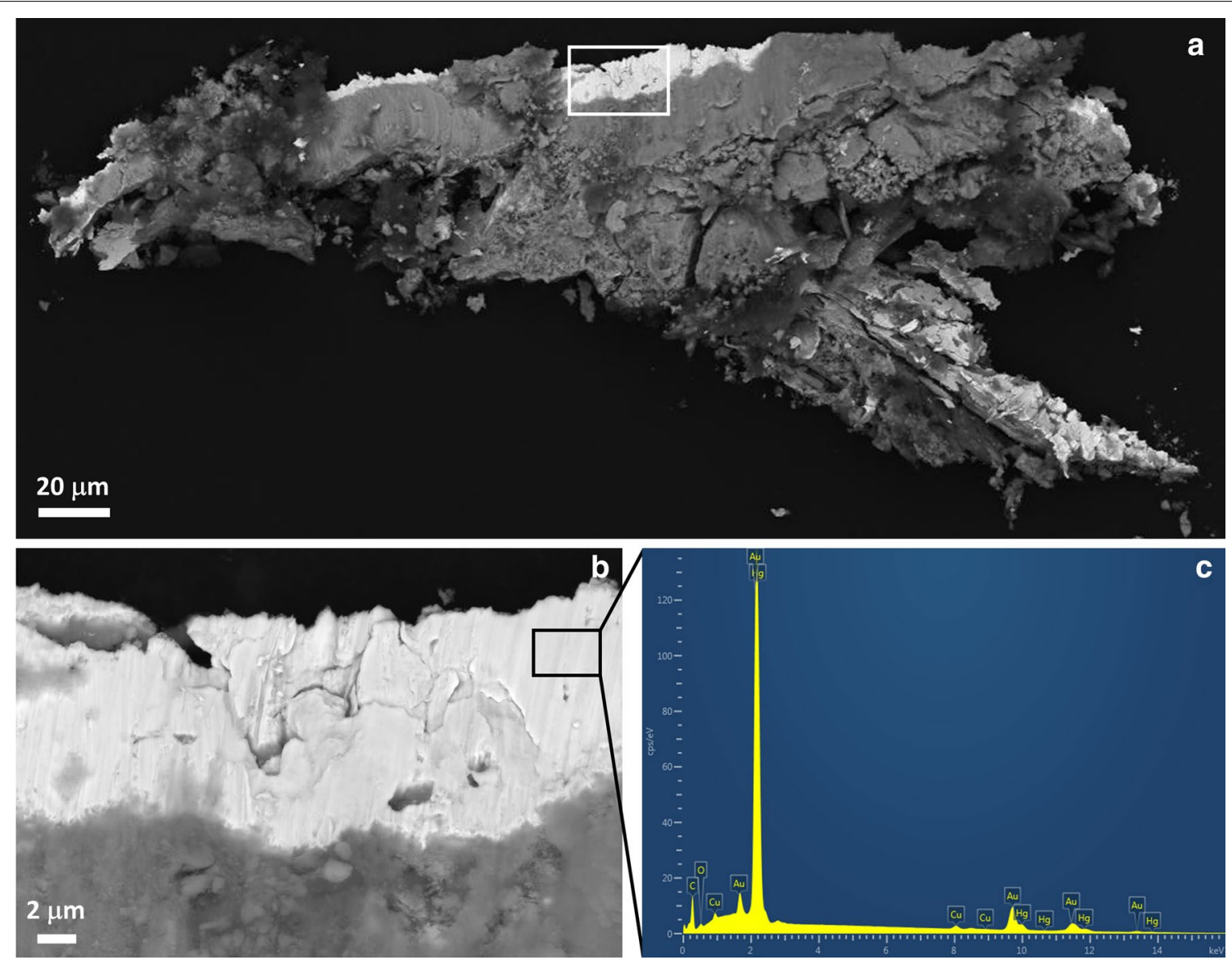

Fig. 8 a Overall BSE image of sample S2, i.e. a scraping of the gilding. b BSE image of the gilding (white square). c EDS spectrum of the gilding (black square) 


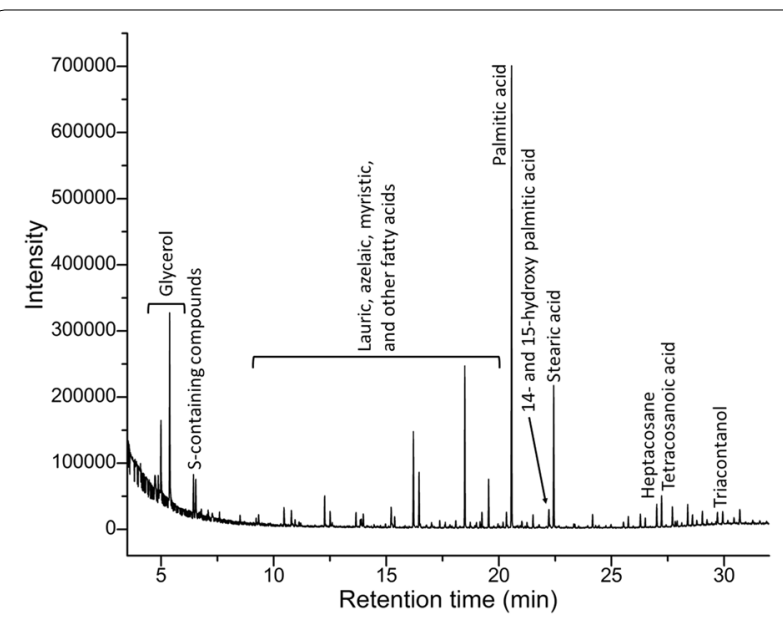

Fig. 9 Py-GC/MS chromatogram obtained upon derivatization with TMAH of sample S1, i.e. a scraping of the black organic coating. Compounds identified in the chromatogram suggest the presence of beeswax, an oil or mixture of oils, and a sulfur-containing material
Two microscopic samples of the gilding (Table 1) were removed from The Frick statuette, one from within the recessed area of the original panpipes (S2) and another from the restoration shield (S3). SEM/EDS detected relatively pure gold $(\mathrm{Au})$ and mercury $(\mathrm{Hg})$ in both samples (Fig. 8), confirming the use of mercury amalgam gilding for the figure and the shield. However, scientific analysis was unable to highlight any difference between the composition of the amalgam on the 15th-century figure and that applied to the later replacement shield.

\section{Organic coating}

To understand how the later black coating on The Frick statuette compares to results from studies of early organic surface treatments on bronzes, a scraping of the black restoration coating (S1) was removed from the back right knee for analysis with Py-GC/MS, Raman, and FTIR spectroscopies. Raman spectroscopy was performed to investigate the possible use of any pigments that may be responsible for the black coloration of the coating. Two broad Raman bands at about 1375 and $1550 \mathrm{~cm}^{-1}$ were identified as unambiguous fingerprints of a carbon-based black. The Py-GC/MS chromatogram obtained upon TMAH derivatization (Fig. 9) contains the typical marker compounds for beeswax: significant amounts of palmitic acid with smaller quantities of stearic acid; hydroxy fatty acids, including 15- and 14-hydroxy palmitic acids; series of high molecular weight fatty acids, with tetracosanoic acid (C24) as the most prominent; series of high molecular weight fatty alcohols, with triacontanol (C30) as the most prominent; and series of normal saturated alkanes, with heptacosane $(\mathrm{C} 27)$ as the most prominent. The

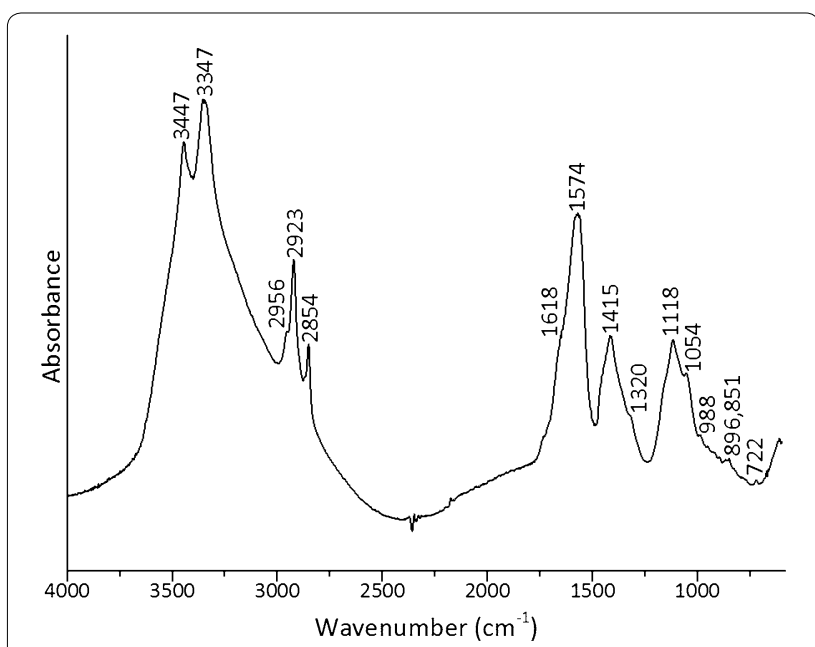

Fig. 10 FTIR spectrum of sample S1, i.e. a scraping of the black organic coating. Materials identified include atacamite, oxalates, and metal carboxylates presence of beeswax in the restoration coating layers might be due to later routine maintenance of the surface by waxing, aiming to provide a barrier coating against harmful environmental conditions [56], and to improve the sculpture's appearance by saturating the surface and imparting a gloss [57]. Moreover, the detection of glycerol along with a series of fatty acids is indicative of the presence of an oil, or a mixture of oils, which is consistent with the use of oils as a surface coating from the Renaissance period onward [21,58]. Due to the complex mixture of substances identified in the sample, it was not possible to provide a detailed characterization of the type of oil(s) present or to rule out the presence of other animal fats. The results show that despite this being a later coating, some of its components, such as oils and pigments, have been identified on early bronzes, demonstrating how difficult it can be to distinguish between original and later surface treatments.

\section{Alteration products}

Sulfur-containing compounds were also detected in the chromatogram of sample S1. These may have resulted from a variety of factors, including exposure to atmospheric pollutants or cleaning agents. Although sulfurcontaining salts have been used since the late Renaissance to darken bronzes [59-61], their use on the Shield Bearers seems unlikely, since the presence of chemically resistant gilding would have prevented any later chemical patination. FTIR in transmission mode identified atacamite, oxalates, and metal carboxylates as the main components of sample S1 (Fig. 10). Atacamite $\left(\mathrm{Cu}_{2}(\mathrm{OH})_{3} \mathrm{Cl}\right)$, characterized by distinctive bands at $3447,3347,988,896$, and 
$851 \mathrm{~cm}^{-1}$, is a characteristic product whose presence is often related to a bronze corrosion process [62]. This compound is frequently detected in corroded bronze sculptures, sometimes in association with its polymorphs clinoatacamite or paratacamite, or a combination of both. The presence of chlorides on The Frick statuette is most likely the result of modern surface treatments with chloride-containing products, such as polishing compounds or pigmented waxes. Oxalates, on the other hand, with distinctive peaks at 1618 and $1320 \mathrm{~cm}^{-1}$, are insoluble salts that typically form as a result of biodeterioration of organic materials; on metal artworks, these are generally found in the organic fraction of the patina or develop from the application of waxes, such as the beeswax detected by Py-GC/MS analysis. A broad FTIR band detected at $1574 \mathrm{~cm}^{-1}$ is indicative of the presence of a wide range of metal carboxylates, which might originate from the interaction of the oil or mixture of oils contained in the organic coating with metallic ions from the brass [55]. Although scientific analysis could not determine possible dates for the application of the later coatings, the data collected during the course of this survey may be helpful in advancing ongoing comparative studies of early bronze surface treatments.

\section{Conclusions}

The attribution of Italian Renaissance bronze statuettes, whose popularity rose during the 15th century and continued to thrive until the late 17 th century, poses several challenges from an art historical point of view, most notably due to the significant loss of many of these bronzes and related archival documentation. The technical examination and scientific analysis of bronzes continues to be a useful and valuable approach in possibly answering materials-related questions, as well as in dating and in the identification of later alterations; however, the amount of data published on 15th-century casts remains limited.

Bertoldo di Giovanni is one of the earliest Florentine artists working in this medium, and his relationships with not only Lorenzo the Magnificent, but many of the prominent artists at the time, make him a crucial figure to study for interpreting the casting of small statuettes. The Frick Collection's exhibition of Bertoldo's sculptural work, held between September 2019 and January 2020, provided an impetus to carry out a technical investigation in an attempt to substantiate the current art historical attributions through examination and scientific analysis. The Frick Shield Bearer was thus analyzed using a combination of instrumental techniques in order to shed light on the casting and fabrication methods, metal alloy composition, as well as materials used in the original and later surface treatment of the bronze. Results obtained from this work, in combination with a comparative study of a second pendant bronze currently in the Liechtenstein Collection, Vienna, have provided insight into the extent and history of the repairs made to both statuettes. Analysis of the metal alloy revealed that they were cast using a virtually identical brass alloy, indicating that they were likely created at the same time, and dispelling any doubt that these two statuettes were conceived as a pair.

A combination of radiography, XRF, and SEM/EDS helped in distinguishing between original areas and replacement components of The Frick statuette, through close comparison with the attributes of the Liechtenstein figure. Of particular relevance is the affirmation that the base of The Frick Shield Bearer, which is missing from the Liechtenstein statuette, is original to the composition. It is currently assumed that the Liechtenstein statuette had a similar base, which was lost due to damage or intentional alteration. No information is available about the display of these two Shield Bearers in the 15th century or how they would have been used in a secular household. The unusual fabrication of The Frick statuette's base, which is composed of $99 \mathrm{wt} \% \mathrm{Cu}$ and soldered together with a $\mathrm{Cu}-\mathrm{Ag}$ alloy, provides a rare example of a type of base not typically observed on later Italian Renaissance bronzes, which are generally cast in one piece using a $\mathrm{Cu}$ alloy.

Analysis by means of SEM/EDS, Py-GC/MS, Raman, and FTIR was also conducted to investigate the materials used in the surface treatments, with a special focus on the original gilding and organic coatings. Results have shown that both statuettes are characterized by a mercury amalgam gilding, while the organic coating was found to contain mainly beeswax and an oil or mixture of oils, pigmented with a carbon-based black-all typical components of early Renaissance bronze treatments-but clearly a later treatment in this case. Similarly, while SEM/EDS analysis was key to establish the exact materials' composition for the gilding, it did not provide evidence to help distinguish between early and later applications. However, the results obtained from the analysis of the organic coatings on The Frick statuette will assist in the interpretation of similar ongoing studies of 15 th- to 18 th-century organic patinas. In addition, the identification of the corrosion products that have developed on their surfaces may be helpful in determining future treatment options. Most importantly, the results of the present study of the Shield Bearers were placed in context within a larger investigation of the artist's casts, unambiguously clarifying that these two statuettes form a unique production in the body of surviving bronzes by Bertoldo. 


\section{Abbreviations}

X-radiography: X-ray radiography; $\mu$ XRF: Micro-X-ray fluorescence spectroscopy; pXRF: Portable X-ray fluorescence spectroscopy; SEM/EDS: Scanning electron microscopy with energy-dispersive X-ray spectroscopy; FTIR: Fouriertransform infrared spectroscopy; Py-GC/MS: Pyrolysis-gas chromatography/ mass spectrometry.

\section{Acknowledgements}

The authors would like to thank the following individuals and institutions. The Frick Collection: Aimee Ng, Noelle Alexander, and Xavier Salomon, whose exhibition was the impetus for this research, as well as Joseph Godla and Gianna Puzzo; The Liechtenstein Collection: Johann Kräftner, Alexandra Hanzl, and Robert Wald for allowing the study of their statuette; The Metropolitan Museum of Art: Federico Carò, Adriana Rizzo, and Richard E. Stone for their guidance in interpreting the data, and Denise Allen and Lisa Pilosi for their support of the project; Buffalo State College: Aaron N. Shugar for assistance in creating a calibration for The Frick's portable XRF system.

\section{Authors' contributions}

EB performed $\mu X R F$ and SEM/EDS of The Frick statuette, along with data interpretation; FP conducted Py-GC/MS, Raman, and FTIR analysis and data interpretation for the same bronze; JD carried out pXRF on the Liechtenstein Shield Bearer, as well as all other statuettes, reliefs, and medals used for comparison; LB performed digital X-radiography. EB drafted the article, with contributions from FP, JD, and LB. All authors read and approved the final manuscript.

\section{Funding}

This research was made possible by the Network Initiative for Conservation Science (NICS), a Metropolitan Museum of Art program. Support for NICS was provided by a grant (31500630) from The Andrew W. Mellon Foundation.

\section{Availability of data and materials}

All data generated during this study are included in this published article or are available from the corresponding author on reasonable request.

\section{Competing interests}

The authors declare that they have no competing interests.

\section{Author details}

${ }^{1}$ Department of Scientific Research, The Metropolitan Museum of Art, 1000 Fifth Avenue, New York, NY 10028, USA. ${ }^{2}$ Department of Conservation, The Frick Collection, 1 East 70th Street, New York, NY 10021, USA. ${ }^{3}$ Sherman Fairchild Center for Objects Conservation, The Metropolitan Museum of Art, 1000 Fifth Avenue, New York, NY 10028, USA.

Received: 1 July 2020 Accepted: 22 October 2020

\section{Published online: 03 November 2020}

\section{References}

1. Draper JD. Bertoldo di Giovanni, sculptor of the medici household: critical reappraisal and catalogue raisonné. Columbia: University of Missouri Press; 1992

2. Bell PJ. The Bronze statuette in Fifteenth-century Florence and Bertoldo di Giovanni. In: Ng A, Noelle AJ, Salomon XF, editors. Bertoldo di Giovanni: The Renaissance of sculpture in Medici Florence. New York: The Frick Collection; 2019. p. 51-80.

3. Bearzi B. Considerazioni di tecnica sul S. Ludovico e la Giuditta di Donatello. Bollettino d'Arte Arte. 1951;36(2):119-23.

4. Stone RE. Antico and the development of bronze casting in Italy at the end of the Quattrocento. Metrop Mus J. 1981;16:87-116.

5. Darr AP. An early Renaissance bronze attributed to Bartolomeo Bellano. Bull Detroit Inst A. 1999;73(12):60-71.

6. Stone RE. A new interpretation of the casting of Donatello's "Judith and Holofernes". Stud Hist Art. 2001:62:54-69.

7. Siano S. Considerazioni tecniche. II ritorno d'Amore, I'Attis di Donatello restaurato. Firenze: Editore SPES; 2005. p. 85-97.

8. Radke GM, editor. The Gates of Paradise: Lorenzo Ghiberti's Renaissance Masterpiece. New Haven and London: Yale University Press; 2007.
9. Ferretti M, Siano S. The gilded bronze panels of the Porta del Paradiso by Lorenzo Ghiberti: non-destructive analyses using X-ray fluorescence. Appl Phys A. 2008:90(1):97-100.

10. Teodori B, Nicolai L. Donatello (Donato di Niccolò di Betto Bardi, Firenze 1386 ca 1466): San Ludovico di Tolosa 1422-1425. Kermes: la rivista del restauro. 2012(87):7-17

11. Siano S, Agresti J. Archaeometallurgical characterisation of Donatello's Florentine copper alloy masterpieces using portable laser-induced plasma spectroscopy and traditional techniques. Stud Conserv. 2015;60(sup1):S106-19.

12. Smith D. Observations on Verrocchio's Bronzes: metal, methods, and models. Verrocchio. 2019:22:311.

13. Day J. Bertoldo, a carver in bronze. In: Ng A, Noelle AJ, Salomon XF, editors. Bertoldo di Giovanni: The Renaissance of sculpture in Medici Florence. New York: The Frick Collection; 2019. p. 231-72.

14. Noelle AJ. Reframing Bertoldo and his legacy. In: Ng A, Noelle AJ, Salomon XF, editors. Bertoldo di Giovanni: The Renaissance of sculpture in Medici Florence. New York: The Frick Collection; 2019. p. 19-50.

15. Bode, W. Denkmaler der Renaissance-Skulptor Toscanas. Munich; 1905. p. 134.

16. Ashley-Smith J. The Technical Examination of Bronze Statuettes. Med Sci Law. 1974;14(1):4-6.

17. Bewer FG. A study of the technology of Renaissance bronze statuettes. Volume I. PhD Thesis 1996.

18. Weisman BM, Reedy CL. Technical studies on Renaissance bronzes. Mat Res Soc Symp Proc. 2002;712:II10.1.1-1.13.

19. Siano S, Bertelli P, Marinelli F, Miccio M. Casting the panels of the Gates of Paradise. In: Radke GM, editor. The Gates of Paradise: Lorenzo Ghiberti's Renaissance Masterpiece. New Haven and London: Yale University Press; 2007. p. 141-55.

20. van Langh R, Lehmann E, Hartmann S, Kaestner A, Scholten F. The study of bronze statuettes with the help of neutron-imaging techniques. Anal Bioanal Chem. 2009:395:1949-59.

21. Pitthard V, Stone R, Stanek S, Griesser M, Kryza-Gersch C, Hanzer H. Organic patinas on Renaissance and Baroque bronzes-Interpretation of compositions of the original patination by using a set of simulated varnished bronze coupons. J Cult Herit. 2011;12:44-53.

22. van Langh R, Bartoli L, Santisteban J, Visser D. Casting technology of Renaissance bronze statuettes: the use of TOF-neutron diffraction for studying afterwork of Renaissance casting techniques. J Anal At Spectrom. 2011;26:892-8.

23. van Langh $R$, James J, Burca G, Kockelman W, Zhang SY, Lehmann E, Erstermann M, Pappot A. New insights into alloy compositions: studying Renaissance bronze statuettes by combined neutron imaging and neutron diffraction techniques. J Anal At Spectrom. 2011;26:949-58.

24. Formigli E. Ghiberti's Saint Matthew and Roman Bronze Statuary: Technical Investigations during Restoration. Stud Hist Art. 2012;76:243-56.

25. Boon JJ, van Langh R. Comprehensive studies of patinas on Renaissance bronze statuettes with laboratory, synchrotron and neutron-aided techniques. In: Bridgland J, editor. ICOM-CC 17th Triennial Conference Preprints. Paris: International Council of Museums; 2014. p. 1-7.

26. Bassett J. The craftsmen revealed. Adriaen de Vries Sculptor in bronze. Los Angeles: Getty Publication; 2008.

27. Lalli C, Pinna D, Porcinai S, Rizzi M. Le indagini Scientifiche. In: Paolozzi Strozzi B, editor. II ritorno d'Amore, I'Attis di Donatello restaurato. Florence: Museo Nazionale del Bargello; 2005. p. 117-21.

28. Stone RE. Organic Patinas on Small Bronzes of the Italian Renaissance. Metrop Mus J. 2010:45:107-24.

29. Degano I, Modugno F, Colombini MP. Characterisation of organic patinas on indoor bronze sculptures. InArt'11 10th International Conference on non-destructive investigations and microanalysis for the diagnostics and conservation of cultural and environmental heritage 2011

30. Galeotti M, et al. Patinature, protettivi, puliture, depositi, alterazioni: il contributo delle analisi scientifiche all'identificazione dei materiali di superficie. In: Mazzoni DM, editor. L'ultimo Donatello. I pulpiti di San Lorenzo: studi e restauro. Firenze: Edifir; 2020

31. Glinsman LA, Hayek LC. A multivariate analysis of Renaissance portrait medals: an expanded nomenclature for defining alloy composition. Archaeometry. 1993;35(1):49-67. 
32. Lutz J, Pernicka E. Energy dispersive X-ray analysis of ancient copper alloys: empirical values for precision and accuracy. Archaeometry. 1996;38(2):313-23.

33. Glinsman LA. The application of X-ray fluorescence spectrometry to the study of museum objects. Amsterdam: Elsevier; 2004

34. van Langh R, Pappot A, Creange S, Megens, L, Joosten I. The effect of surface changes in heat-treated bronze samples analysed by X-ray fluorescence spectrometry. In: Proceedings of METAL 2010. Charleston: ICOM-CC; 2010. p. 204-9.

35. Smith D. The application of alloy analysis to questions of attribution: Giovanni Francesco Susini and the workshop of Giambologna. In: Mardikian P, Chemello P, Watters C, and Hull P, editors. Proceedings of METAL 2010. Charleston: Clemson University; 2011. p. 256-265.

36. Bonizzoni L, Galli A, Poldi G. In situ EDXRF analyses on Renaissance plaquettes and indoor bronzes patina problems and provenance clues. X-Ray Spectrom. 2008;37(4):388-94.

37. Heginbotham A, Bassett J, Bourgarit D, Eveleigh C, Glinsman L, Hook D, Smith D, Speakman RJ, Shugar A, van Langh R. The Copper CHARM Set: a new set of certified reference materials for the standardization of quantitative $X$-ray fluorescence analysis of heritage copper alloys. Archaeometry. 2015;57(5):856-68.

38. Drake BL. CloudCal version v2.0. https://doi.org/10.5281/zenodo.13198 18. https://zenodo.org/record/1319818\#.XtAZEjpKhPY. Accessed 28 May 2020.

39. Smith D, Sturman S. The art and innovation of Antico's bronzes: a technical investigation. In: Antico. The golden age of Renaissance bronzes. Washington; 2012. p. 157-77.

40. Smith D. Copper alloy use in Sixteenth Century Northern Italy associated with the workshop of Severo da Ravenna. In: Thomas N, Dandridge P, editors. Cuivres, bronzes et laitons médiévaux. Histoire, archéologie et archéométrie des productions en laiton, bronze et autres alliages à base de cuivre dans l'Europe médiévale (12e-16e siècles). Namur: Patrimoine Publications; 2018. p. 285-96.

41. Han K, Embury JD, Sims JR, Campbell LJ, Schneider-Muntau HJ, Pantsyrnyi VI, Shikov A, Nikulin A, Vorobieva A. The fabrication, properties and microstructure of $\mathrm{Cu}-\mathrm{Ag}$ and $\mathrm{Cu}-\mathrm{Nb}$ composite conductors. Mater Sci Eng A. 1999;267(1):99-114.

42. Biringuccio V. 1540. De La Pirotechnia, The Classic Sixteenth-Century Treatise on Metals and Metallurgy, Smith, CS and Gnudi, MT.

43. Cellini B. The treatise of Benvenuto Cellini on goldsmithing and sculpture. Translated by CR Ashbee. London, 1898. Repr. New York, 1967.

44. Scott DA. Technological, analytical, and microstructural studies of a Renaissance silver basin. Archeomaterials. 1991;5(1):21-45.

45. Ogden J. Age and authenticity: the materials and techniques of 18th and 19th century goldsmiths. London, 1999.

46. Ng A, Noelle AJ, Salomon XF, editors. Bertoldo di Giovanni: The Renaissance of sculpture in Medici Florence. New York: The Frick Collection; 2019.
47. Craddock PT. Copper alloys of the Hellenistic and Roman world: new analyses and old authors. In: Jones JE, editor. Aspects of ancient mining and metallurgy. Bangor: Acta of a British School at Athens Centenary Conference; 1986. p. 55-65.

48. Anheuser K. The practice and characterization of historic fire gilding techniques. JOM. 1997;49(11):58-62.

49. Vasari G. Vasari on technique. Baldwin Brown G, editor, Maclehose LS, trans. London: Dent. 1907.

50. Scaglia G. A Miscellany of Bronze Works and Texts in the" Zibaldone" of Buonaccorso Ghiberti. Proc Am Philos Soc. 1976;120(6):485-513.

51. Gaurico P. De sculptura. Florence, 1504. Translated by Paolo Cutolo, Naples, 1999.

52. Hughes $R$, Rowe M, editors. The colouring, bronzing and patination of metals: a manual for the fine metalworker and sculptor. New York: Watson-Guptill Publications; 1991

53. Hughes R. Artificial patination. In: La Niece S, Craddock P, editors. Metal plating and patination. Oxford: Butterworth-Heinemann; 1993. p. 1-18.

54. Bewer FG. Studying the technology of Renaissance bronzes. In: JR Druzik, JL Galvan Madrid, IC Freestone, GS Wheeler (Eds.), MRS Proceedings IV. 1995;352:701-709.

55. Scott DA. Copper and bronze in art, corrosion, colorants conservation. Los Angeles: Getty Publications; 2002.

56. Couture-Rigert DE, Sirois PJ, Moffatt EA. An investigation into the cause of corrosion on indoor bronze sculpture. Stud Conserv. 2012;57(3):142-63.

57. Pitthard V, Stanek S, Griesser M, Hanzer H, Kryza-Gersch C. Comprehensive investigation of the 'organic patina' on Renaissance and Baroque indoor bronze sculptures from the collection of the Kunsthistorisches Museum, Vienna. In: Townsend JH, Toniolo L, Cappitelli F, editors. Conservation Science 2007. Milan, Italy, Archetype Publications: London; 2008. p. 49-55.

58. Stone RE, White R, Indictor N. Surface composition of some Italian renaissance bronzes. In: ICOM Committee for Conservation, 9th triennial meeting. Dresden: ICOMCC Los Angeles; 1990. p. 568-73.

59. Hiorns $\mathrm{AH}$. Metal colouring and bronzing. London-New York: Mc Millian and $\mathrm{CO} ; 1902$

60. Bongiorno V, Campodonico S, Caffara R, Piccardo P, Carnasciali MM. Micro-Raman spectroscopy for the characterization of artistic patinas produced on copper-based alloys. J Raman Spectrosc. 2012;43(11):1617-22.

61. Piccardo P, Bongiorno V, Campodonico S. Artistic patinas on ancient bronze statues. In: Corrosion and conservation of cultural heritage metallic artefacts. Sawston: Woodhead Publishing; 2013. p. 193-212.

62. Scott DA. A review of copper chlorides and related salts in bronze corrosion and as painting pigments. Stud Conserv. 2000:45(1):39-53.

\section{Publisher's Note}

Springer Nature remains neutral with regard to jurisdictional claims in published maps and institutional affiliations.

\section{Submit your manuscript to a SpringerOpen ${ }^{\odot}$ journal and benefit from:}

- Convenient online submission

- Rigorous peer review

- Open access: articles freely available online

- High visibility within the field

Retaining the copyright to your article

Submit your next manuscript at springeropen.com 